\title{
'Szakpolitika, rendszer, környezet' megközelítés az elhízás megelőzésében: elméleti keretek helyi és állami beavatkozásokhoz
}

\author{
Policy, Systems, and Environmental Approaches for Obesity Prevention: \\ A Framework to Inform Local and State Action
}

Ismertető: Vitrai József $\square$

Emberi Erőforrások Minisztériuma

Szerzők: Lyn R, Aytur S, Davis TA, Eyler AA; Evenson KR, Chriqui JF, Cradock AL, Goins KV, Litt J, Brownson RC Megjelenés: Journal of Public Health Management Practice, 2013, 19(3) E-Supp, S23-S33;

DOI: 10.1097/PHH.0b013e3182841709

Beküldve: 2017.09.13.

doi: 10.24365/ef.v58i3.177

Kulcsszavak: ökológiai modell; rendszerszemléletű, többszintű megközelítés

\section{ÖSSZEFOGLALÁS}

2002-ben az USA Országos Orvosi Intézete, felismerve az egyén egészségmagatartásának megváltoztatására irányuló népegészségügyi beavatkozások eredménytelenségét olyan ökológiai modell alkalmazását javasolta, amelyben az egyént és viselkedését az ő tágabb társadalmi és környezeti helyzete határozza meg. Ennek megfelelően a kutatók „rendszerszemléletű, többszintű megközelítést ajánlanak, amelyben az elhízást összekapcsolt, változó és egymáshoz alkalmazkodó tényezők befolyásolhatják". Ez alapján fogalmazódott meg a 'Szakpolitika, rendszer, környezet' stratégia, melynek alkal- mazásához dolgozták ki a cikkben ismertetett elméleti keretet a szerzők. Az elméleti keret három területe (probléma, szakpolitika, politika) hat tevékenységet foglal magába. (1. ábra)

Valamennyi tevékenységhez megvalósult példákat mutatnak be, és megadják a szakmai munkát támogató - többnyire az amerikai népegészségügyi intézet, a CDC által kifejlesztett -, segédanyagok forrását, elérhetőségét. Írásukkal a népegészségügyi szakemberek számára kívánnak segítséget nyújtani ahhoz, hogy eredményesen tudják befolyásolni a szakpolitikát az elhízás megelőzésében.

\section{KULCSÜZENET A SZAKEMBEREK SZÁMÁRA}

Az elhízás megelőzéséhez, visszaszorításához - hasonlóan a többi népegészségügyi probléma összetettségéhez -, megoldást csak a cikkben bemutatotthoz hasonló szemlélet alapján kialakított szakpolitikák kínálhatnak. A hazai népegészségügyi szakemberek eredményes munkájához a közleményben felsorolt segédanyagok megfelelő magyar változatának kidolgozása nélkülözhetetlen. 
1. ábra: 'Szakpolitika, rendszer, környezet' elméleti keret az elhízás megelözéséhez

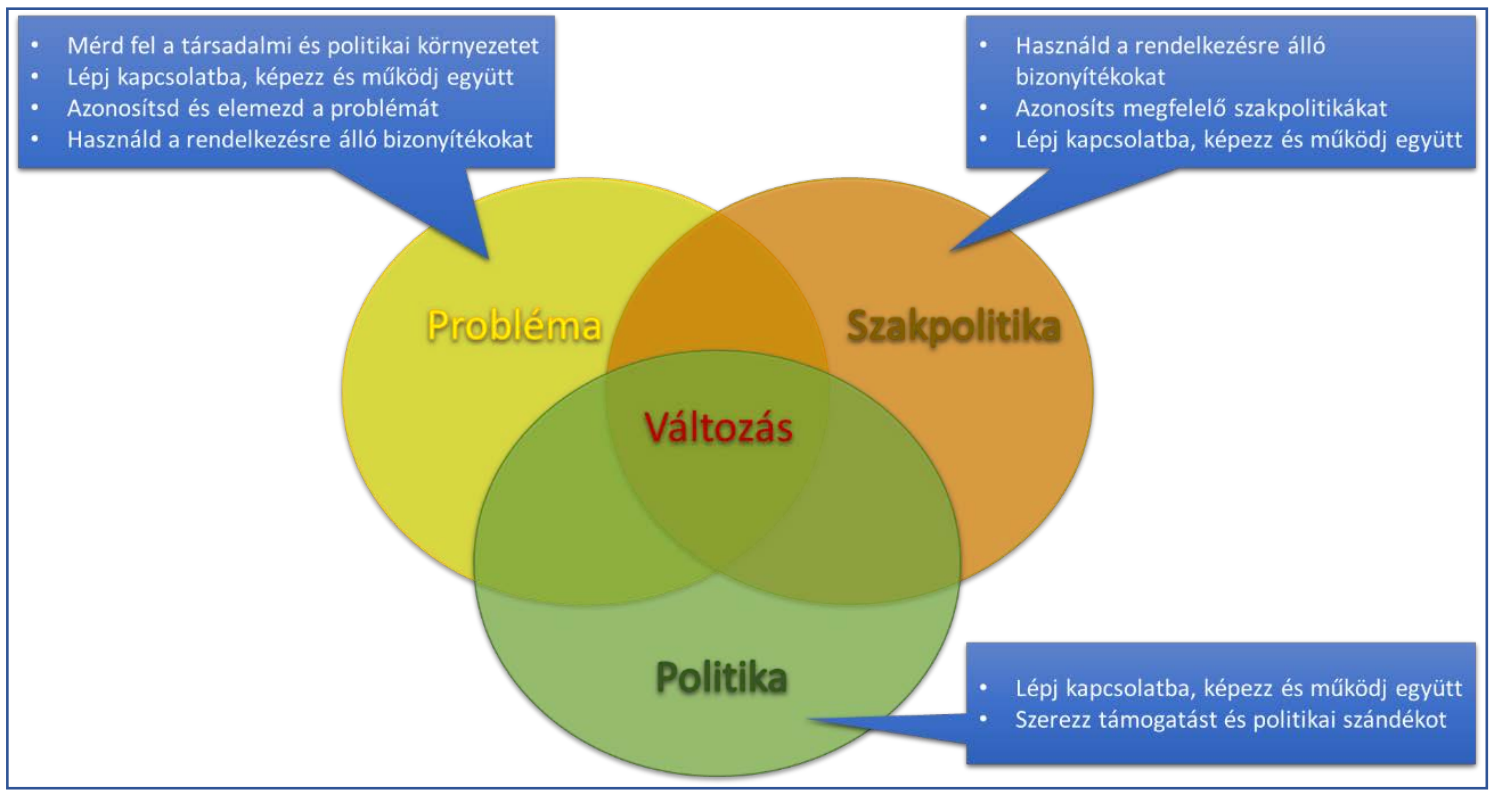

Forrás: az ismertetett cikk 